\title{
A talaj kadmium szennyezettségének vizsgálata angolperje (Lolium perenne L.) bioteszttel
}

\author{
MÓNOK Dávid és FÜLEKY György
}

Szent István Egyetem, Mezőgazdaság- és Környezettudományi Kar, Környezettudományi Intézet, Talajtani és Agrokémiai Tanszék, Gödöllő

\section{Bevezetés}

A kadmiummal szennyezett területek komoly környezeti- és humánegészségügyi kockázatot jelentenek, mivel a kadmium a talajokban toxikus mennyiségben halmozódhat fel anélkül, hogy akut mérgező hatása megnyilvánulna. Emiatt bekerülhet a táplálékláncba, így az emberi szervezetbe is, ott akkumulálódhat, és az élő szervezetek heveny vagy idült károsodását, végső esetben pusztulását idézheti elő (KÁDÁR, 1995; KIRKHAM, 2006; TUDOREANU \& PhILLIPS, 2004; KABATA-PENDIAS, 2010).

A kadmium főként mezőgazdasági és ipari tevékenység révén jut a talajba. A Cd szennyezés mezőgazdasági forrásai közül a foszfor mütrágyák, a szerves és hígtrágyák, valamint a szennyvíziszapok jelentősek, míg az ipari szennyezés vegyipari, műanyagipari, mikroelektronika ipari, valamint bányászati tevékenységek esetén kimagasló. A felszínre került kadmium általában addig a mélységig jut le a talajprofilban, ameddig talajmüveléssel bedolgozzák. Immobilitása miatt veszélyes mértékben is felhalmozódhat a talaj felső rétegében (WUANA \& OKIEMEN 2011; FILEP, 1998; SZABÓ \& FODOR, 1998).

Magyarországon a földtani közeg és a felszín alatti vízszennyezéssel szembeni védelemhez szükséges határértékekről és a szennyezések méréséről a 6/2009. (IV. 14.) KvVM-EüM-FVM együttes rendelet rendelkezik. Ebben a rendeletben foglalt ún. (B) szennyezettségi határérték kadmiumra földtani közegben $1 \mathrm{mg} \mathrm{kg}^{-1}$. Ez a határérték az „összes” elemtartalomra vonatkozik, azonban a környezeti kockázat szempontjából már a gyengébb kivonószerekkel kapott koncentráció-értékek is informatívak lehetnek.

Abban az esetben, ha a talaj kadmium tartalmát környezetvédelmi szempontból értékeljük, a talajban található kadmium mennyiségét analitikai vizsgálatokkal határozzuk meg, majd összevetjük a környezetvédelmi határértékekkel. Ezek az eredmények azonban önmagukban még nem tükrözik a nehézfémek károsító hatását az ökoszisztémára. Ezen probléma megoldására ökotoxikológiai vizsgálati módszereket alkalmazhatunk, melyek alkalmasak lehetnek az ökoszisztéma élőlényeire kifejtett hatások vizsgálatára. Lehetővé teszik továbbá a kadmium mozgásának és felhalmozódásának nyomon követését a táplálékláncon keresztül (GRUIZ et al., 2001; CARDOSO \& ALVES, 2012).

Postai cím: MóNOK DÁvID Szent István Egyetem, Mezőgazdaság- és Környezettudományi Kar, Környezettudományi Intézet, Talajtani és Agrokémiai Tanszék,

Gödöllő, Páter Károly u. 1.,

E-mail: monokdavid27@gmail.com 
Magyarországon a szennyezett talajok ökotoxikológiai vizsgálataira gyakran bakteriális teszteket alkalmaznak. Ezek közül a Pseudomonas fluorescens (MSZ 21470-88:1993), valamint az Azotobacter agile teszt (MSZ 21978-30:1988) a legismertebb. Számos bioteszt alacsonyabb- és magasabb rendü növényeket használ szennyeződések kimutatására, mivel a növények általában érzékenyebbek a szennyezőanyagokra, mint a baktériumok. A magasabb rendü növényekkel végzett toxicitás tesztek mért paraméterei a pusztulás, a növekedés (mérhető hosszban, súlyban) valamint a fotoszintetikus és a metabolikus enzimaktivitások lehetnek. A szabványok többnyire egynyári növényeket és füféléket javasolnak (BABICH \& STOTZKY, 1985; GRUIZ et al., 2001; OECD, 2003).

Szennyezett talajokra a leggyakrabban alkalmazott növényi bioteszt az OECD 208-as számú szárazföldi növény tesztje, amelyben a csírázásgátlást és a hajtás növekedésének gátlását mérik. Magyarországon széleskörüen használják még a fehér mustár (Sinapis alba L.) növekedésgátlási tesztet is (OECD, 2003; MSZ 21976-17:1993).

A növényi biotesztekhez gyakran angolperjét (Lolium perenne L.) használnak fel, amely ökotoxikológiai szempontból kiváló tesztszervezet, mivel fejlődése gyors, paraméterei (pl. hajtáshossz, friss tömeg) jól mérhetőek, laboratóriumi körülmények között könnyen kezelhető, valamint olcsó és széleskörüen elterjedt növény (BARCSÁK, 2004; CARDOSO \& ALVES, 2012).

Korábban a növényekre alapozott bioteszt módszereket elsősorban a tápanyagfelvétel elemzésére alkalmazták. A nehézfémek károsító hatását modellező növényi biotesztek eddig közölt eredményei pedig nagyon eltérőek: a vizsgált talajtípustól, tesztnövénytől, az alkalmazott módszer beállítási és/vagy értékelési paramétereitől függtek (NOOMAN \& FÜLEKY, 1989; BARNA \& FÜLEKY, 2007; KIRKHAM, 2006).

A kadmium mobilitása és növények általi felvehetősége függ annak kémiai formáitól. A talajban előfordulhat oldott formában, kolloidokhoz kötve, talajásványokba zárva és oldhatatlan csapadék formában. Azt, hogy milyen formában van jelen a kadmium a talajban, a talajtulajdonságok erősen befolyásolják. Ezek közül a talaj kémhatása az egyik legfontosabb, mivel a Cd adszorpciója és deszorpciója pH-függő. Köztudott, hogy a nehézfém-kationok mobilitása a pH csökkenésével növekszik, és kadmium esetében már kismértékü pH-csökkenés is fokozza a fém mobilitását (LEHOCZKY et al., 1996; ALLOWAY, 1995).

Korábbi kutatások bizonyították, hogy a pH csökkenésével a növények által felvett kadmium mennyiség is növekszik, és a két érték között lineáris összefüggés van (SAPPIN-DidiER et al., 2005; TUDOREANU \& PHILLIPS, 2004; KIRKHAM, 2006; WUANA \& OKIEMEN, 2011).

Szintén fontos tényező a talaj szervesanyag-tartalma, mivel szerepet játszik a kadmium megkötésében. Így nagyobb szervesanyag-tartalom esetében csökken a növények által felvett kadmium mennyiség (KIRKHAM, 2006; SAUVÉ et al., 2003).

A kadmium felvétele kompetícióban áll más elemek felvételével ( $\mathrm{K}, \mathrm{Ca}, \mathrm{Mg}$, $\mathrm{Fe}, \mathrm{Mn}, \mathrm{Cu}, \mathrm{Zn}, \mathrm{Ni}$ ), ugyanazon membrán transzporter használata miatt. Ezen elemek közül a Zn jelenléte a legfontosabb, mivel kémiailag hasonló tulajdonságokkal rendelkezik, mint a kadmium. A tápanyagellátás szintén 
befolyásolja a Cd felvételét. Korábbi vizsgálatok alapján, a tápanyaggal jól ellátott növények nagyobb mennyiségü kadmiumot vesznek fel a talajból, mint a kevésbé jól ellátott növények (RIVETTA et al., 1997; KIRKHAM, 2006; MENGEL et al., 2001; GÖTHBERG et al., 2004).

A kadmium felvétel után a növény különböző szöveteibe kerül, majd ott felhalmozódhat, nagy mennyiségben károsíthatja is a növényt. A növények kadmium-tartalma függ a növények fejlődési állapotától, a növényi résztől, és az ivartól is. A fiatal növény kadmium-tartalma akár nagyságrenddel is magasabb lehet, mint az érett növényé (KÁDÁR, 1995).

Az egyes növényfajok között jelentős különbség van a hajtás és a gyökér nehézfémtartalmának megoszlási arányában. Korábbi vizsgálatok alapján az angolperje által felvett kadmium nagyrészt a gyökérben halmozódik fel (JONES \& JARVIS, 1981; RAMOS et al., 2002). Ezzel szemben MURÁNYI et al. (1997) magasabb Cd koncentrációt mértek az angolperje hajtásában, mint a gyökerében.

RAMOS et al., 2002; SIMON et al., 1999 a növények hajtása és a talaj kadmium tartalma között általában lineáris összefüggést tapasztaltak.

Az angolperje már alacsony kadmium-koncentráció esetén is nagy mennyiségü kadmiumot akkumulál a gyökérben, illetve a szárban. A növekvő kadmium adagok hatására pedig csökken az angolperje szárának és gyökerének friss tömege (GoLDA \& KORZENIOWSKA, 2016; BIDAR et al., 2006; LEHOCZKY et al., 2002).

BARNA \& FÜLEKY (2007) vizsgálataiból kiderült, hogy az angolperje hajtáshosszára gyakorolt károsító hatás jó mutatója a talaj nehézfémszennyezettségnek. Emiatt az általuk kidolgozott angolperjével végzett gyors növényi bioteszt alkalmas arra, hogy jelzés értékủ, kiegészítő információt adjon a talajszennyezettségi határértéket meghaladó nehézfém-terhelésre, különösen kadmium esetében. A vizsgálatot azonban csak egyféle talajon (barna erdőtalaj) végezték el, így a talaj tulajdonságainak befolyásoló hatásáról nem kaptunk információt. Emiatt elengedhetetlen, hogy különböző talajokon megvizsgáljuk a módszer alkalmazhatóságát.

Kísérletünk során négy különböző tulajdonságokkal rendelkező talajt használtunk fel, melyeket laboratóriumi körülmények között kadmiummal terheltünk, majd megvizsgáltuk a kadmium-terhelés hatásait a tesztnövényre.

Kutatómunkánk során a következő kérdések megválaszolását tüztük ki célul:

A BARNA \& FÜLEKY (2007) által kidolgozott, nehézfémmel szennyezett talajok vizsgálati módszerén alapuló angolperje-bioteszt alkalmazható-e különböző típusú és tulajdonságú talajok ökotoxikológiai vizsgálatára?

A talaj növekvő kadmium koncentrációja milyen hatással van az angolperje által felvett, és hajtásában akkumulált $\mathrm{Cd}$ mennyiségére, valamint az angolperje növekedési paramétereire?

A kadmiummal terhelt talajok ökotoxikológiai tesztelése során milyen időtartamú legyen az angolperje nehézfém-terhelési periódusának időtartama, amely végére a növényi paraméterek kellően differenciálódnak?

Továbbá arra is kerestük a választ, hogy az ökotoxikológiai teszt során mely talajtulajdonságok, hogyan befolyásolják az angolperje kadmium-felvételét a talajból, valamint a különböző növekedési paramétereit? 


\section{Vizsgálati anyag és módszer}

A kísérletben alkalmazott talajminták a talaj felső 0-30 cm-es rétegéből származtak. A kísérlet szempontjából legfontosabb tulajdonságaikat az 1. táblázat tartalmazza.

\section{1. táblázat}

A teszttalajok típusa és tulajdonságai

\begin{tabular}{|c|c|c|c|c|}
\hline $\begin{array}{l}\text { (1) } \\
\text { Származási hely: }\end{array}$ & $\begin{array}{l}\text { Kompolt } \\
\text { (KO) }\end{array}$ & $\begin{array}{l}\text { Nagyhörcsök } \\
\text { (NH) }\end{array}$ & $\begin{array}{l}\text { Nyíregyháza } \\
\text { (NY) }\end{array}$ & $\begin{array}{l}\text { Őrbottyán } \\
\text { (ŐB) }\end{array}$ \\
\hline $\begin{array}{l}(2) \\
\text { Talajtípus: }\end{array}$ & $\begin{array}{l}\text { (a) barna } \\
\text { erdőtalaj }\end{array}$ & $\begin{array}{l}\text { (b) csernozjom } \\
\text { talaj }\end{array}$ & $\begin{array}{l}\text { (c) } \\
\text { homoktalaj }\end{array}$ & $\begin{array}{l}\text { (c) } \\
\text { homoktalaj }\end{array}$ \\
\hline $\begin{array}{l}\mathbf{K}_{\mathbf{A}} \\
\mathbf{p H}_{(\mathrm{H} 2 \mathrm{O})} \\
\mathbf{p H}_{\mathrm{KCl}} \\
\mathrm{CaCO}_{3} \% \\
\text { (3) Humusz \% } \\
\text { (4) Só \% }\end{array}$ & $\begin{array}{l}38 \\
5,9 \\
4,7 \\
<0,1 \\
2,33 \\
0,04\end{array}$ & \begin{tabular}{l|}
36 \\
7,7 \\
6,7 \\
3,47 \\
7,44 \\
0,07 \\
\end{tabular} & $\begin{array}{l}22 \\
5,5 \\
4,9 \\
<0,1 \\
3,09 \\
0,02\end{array}$ & $\begin{array}{l}23 \\
7,4 \\
6,9 \\
2,13 \\
4,17 \\
0,05 \\
\end{array}$ \\
\hline $\begin{array}{l}\mathrm{NH}_{4}-\mathrm{N} \mathrm{mg} \mathrm{kg}^{-1} \\
\mathrm{NO}_{3}-\mathrm{N} \mathrm{mg} \mathrm{kg}^{-1} \\
\mathrm{AL}_{-} \mathrm{P}_{2} \mathrm{O}_{5} \mathrm{mg} \mathrm{kg}^{-1} \\
\mathrm{AL}-\mathrm{K}_{2} \mathrm{O} \mathrm{mg} \mathrm{kg}^{-1}\end{array}$ & $\begin{array}{l}3,3 \\
2,1 \\
187 \\
183 \\
\end{array}$ & $\begin{array}{l}1,3 \\
10,9 \\
296 \\
215\end{array}$ & $\begin{array}{l}4,8 \\
3,5 \\
75 \\
64 \\
\end{array}$ & $\begin{array}{l}3,9 \\
3,6 \\
360 \\
53 \\
\end{array}$ \\
\hline $\begin{array}{l}\text { (5) } \mathrm{Cd} \mathrm{mg} \mathrm{kg}^{-1} \\
\text { (HNO } \text { kivonat) }^{-1} \\
\mathrm{Zn} \mathrm{mg} \mathrm{kg}^{-1} \\
\text { (HNO } \text { kivonat) }^{-}\end{array}$ & $\begin{array}{l}0,76 \\
1,19\end{array}$ & $\begin{array}{l}1,14 \\
4,08\end{array}$ & $\begin{array}{l}0,66 \\
1,24\end{array}$ & $\begin{array}{l}1,15 \\
1,33\end{array}$ \\
\hline
\end{tabular}

A teszttalajok nehézfém-terhelése kadmium-acetát törzsoldat talajba keverésével történt meg. Összesen 4 Cd-terhelési szintet állítottunk be: $0,1,2$, és 4 $\mathrm{mg} \mathrm{kg}{ }^{-1}$-os terhelést. A teszttalajok Cd-terhelése következő lépésekből állt:

200 g légszáraz, előzőleg 2 mm-es szitán átrostált teszttalajt helyeztünk 1-1 db. $500 \mathrm{ml}$ ürtartalmú, $50 \mathrm{~mm}$ belmagasságú és $130 \mathrm{~mm}$ átmérőjü, sima felületü müanyag tálba. Ezután a 4 különböző talajon a fentebb említett Cd-terhelési szinteket alkalmaztuk 3 ismétlésben. Az egyes talajok 60\%-os vízkapacitásának megfelelő mennyiségü desztillált vízbe $0,2 \mathrm{ml} 0 ; 1 ; 2$ vagy $4 \mathrm{mg} / \mathrm{ml} \mathrm{Cd-tartalmú}$ kadmium-acetát $\left[\mathrm{Cd}\left(\mathrm{CH}_{3} \mathrm{COO}\right)_{2}\right]$ törzsoldatot kevertünk, és ezt hozzáadtuk a $200 \mathrm{~g}$ talajmintákhoz.

A kísérlet módszertani alapelve a BARNA \& FÜLEKY (2007) által kidolgozott, nehézfémmel szennyezett talajok toxicitását értékelő, gyors növényi bioteszt volt. A kísérlet 2 részből épül fel: egy előnevelési és egy terhelési periódusból.

Az előnevelési periódusban 48 db 500 ml ürtartalmú, 50 mm belmagasságú és 130 mm átmérőjü, sima felületü mủanyag tálba 2-2 g háztartási vattát helyeztünk, amelyeket $30 \mathrm{ml} /$ tenyészedény desztillált vízzel átitattunk és a nedves vattapárnákra egyenletesen elosztva 2 g/tenyészedény vetőmag mennyiségeket juttattunk. Az így előkészített csíráztató tálakban az angolperjét 6 napig, $25^{\circ} \mathrm{C}$ hőmérsékleten 
csíráztattuk és előneveltük, amely során naponta a fent említett tömegállandóságra öntöztük desztillált vízzel az edényeket. A tenyészedények helyét a növénynevelő asztalon véletlenszerủen cseréltük. A csíráztatás időtartama alatt a tenyészedényeket papírívekkel teljes terjedelmükben lefedtük, majd amint a csíranövények elérték az átlagosan 10-15 mm-es hajtáshosszt, a papíríveket eltávolítottuk.

Az előnevelt növényeket tartalmazó vattapárnákat az előnevelési periódus zárónapján az előzetesen kadmiummal terhelt talajmintákra helyeztük. A $200 \mathrm{~g}$ teszttalajt tartalmazó tenyészedényeket kadmium-terhelési szintenként 3 ismétlésben, véletlen elrendezésben helyeztük el. A terhelési periódus alatt a tenyészedényeket $25{ }^{\circ} \mathrm{C}$ hömérsékleten tartottuk, valamint naponta tömegállandóságra öntöztük desztillált vízzel.

A nehézfém-terhelési időszak alatt 2 naponta mértük az angolperje hajtáshosszát $(\mathrm{mm})$, melyet minden tenyészedényben 8 ponton detektáltunk. A kör alakú tenyészedényt 4 részre osztva, a körátlók mentén a tenyészedény középpontjától 2 és $4 \mathrm{~cm}$ távolságra mértük a hajtáshosszt, majd a $8 \mathrm{db}$ mért értéket átlagoltuk. Így a terhelési periódusban a 0., 2., 4., 6., 8., 10., 12., és a 14. napon keletkeztek eredmények.

A nehézfém-terhelési periódus végén, a 14. napon az angolperje hajtásait tenyészedényenként levágtuk a vattapárnákról, és lemértük a hajtás friss tömegét (g/tenyészedény). Ezután szobahőmérsékleten légszárazra kiszárítottuk a hajtásokat, és mértük a száraztömegüket (g/tenyészedény), majd a meglévő adatokból kiszámoltuk az angolperje hajtásának nedvességtartalmát (\%).

A növekedési paramétereken kívül, mértük a hajtás Cd koncentrációját (mg $\mathrm{kg}^{-1}$ szárazanyag), amelyet sósavas hidrolízist követően atomabszorpciós spektrofotométer segítségével határoztunk meg. A sósavas hidrolízis a következők szerint történt: $0,5 \mathrm{~g}$ légszáraz hajtásmintát $10 \mathrm{ml} 2 \mathrm{M}$ sósavoldattal $105{ }^{\circ} \mathrm{C}$-on 3 órán keresztuil hidrolizáltunk. Lehülés után $10 \mathrm{ml}$-re feltöltöttük az oldatot desztillált vízzel, majd homogenizálás után átszürtük.

$\mathrm{Az}$ eredmények értékeléséhez az adatok elemzését varianciaanalízissel végeztük. A talaj kadmium terhelése és a növényi paraméterek közötti összefüggést regresszióanalízissel állapítottuk meg. A különböző talajokon kapott eredmények összehasonlítására a Tukey-féle post hoc tesztet alkalmaztuk. A talaj tulajdonságai és a növény paraméterei közötti összefüggést pedig a Pearson-féle korrelációs együtthatóval (r) jellemeztük.

Továbbá feltüntettük az akut toxicitás $\mathrm{EC}_{10}$, és $\mathrm{EC}_{20}$ értékeit is, amelyek azok a kadmium-terhelési szintek, ahol a bioteszt mért paraméterében 10 és $20 \%$-os a csökkenés a kontrollhoz képest.

\section{Vizsgálati eredmények}

\section{Az angolperje hajtásának növekedése a terhelési periódusban}

A hajtás növekedése a terhelési periódusban eltelt napok függvényében a 1 . ábrán látható, ahol a hajtáshossz változásait a terhelési periódus 0 . napján mért értékekhez hasonlítottuk. Az ábráról megállapítható, hogy az egyes Cd-terhelések eltérő mértékben befolyásolták a hajtás növekedését, és az idő elteltével a mért 
értékek egyre jobban differenciálódtak. Megfigyelhető továbbá az is, hogy ez a differenciálódás egyes talajok esetében eltérő.
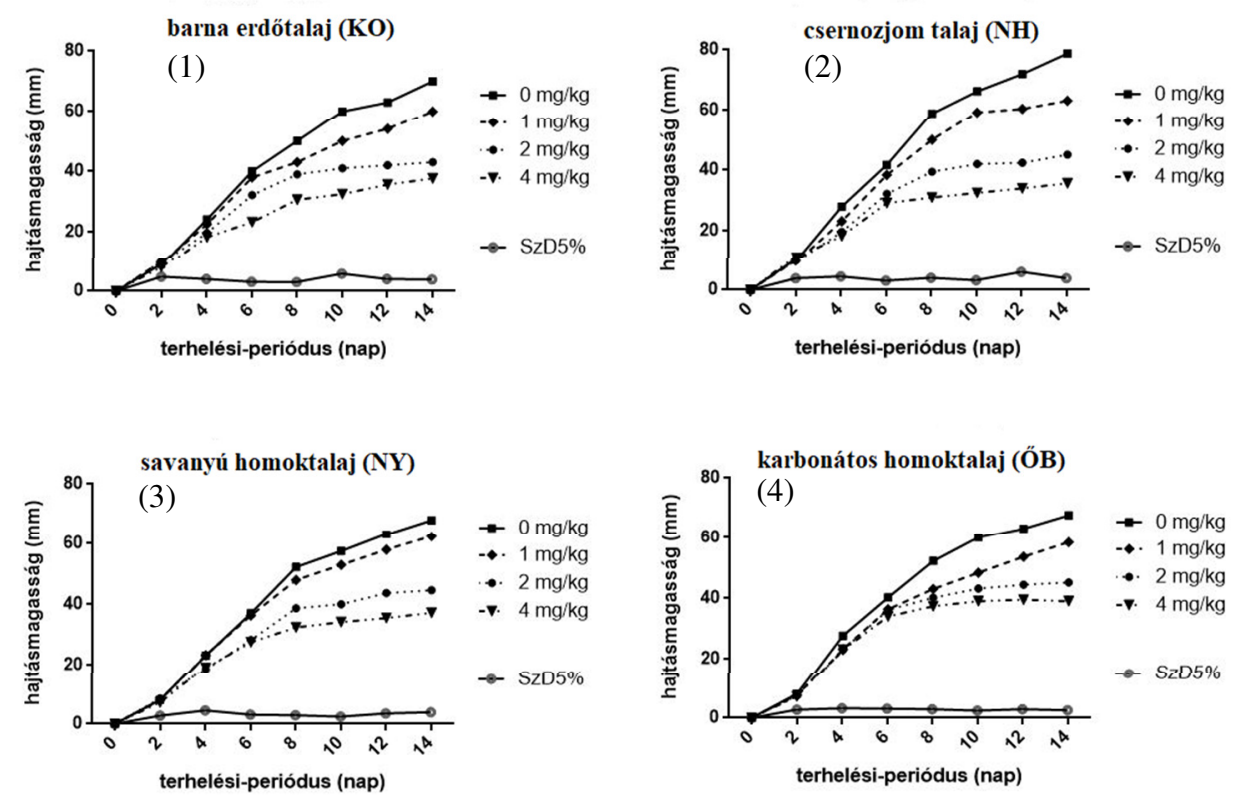

1. ábra

A hajtás növekedése a terhelési periódusban (KO: Kompolt; NH: Nagyhörcsök; NY: Nyíregyháza; ÖB: Örbottyán)

A 2. és 4. napon mért hajtáshosszúságok esetében nem volt szignifikáns különbség a terhelések között ( $\mathrm{p}>0,05)$. A 6 . napon mért hajtáshosszúságok között már nagyobb különbségeket találunk az egyes $\mathrm{Cd}$ terhelések között, azonban a különbség még ekkor sem szignifikáns $(\mathrm{p}=0,07)$.

A 8. napon mért hajtáshossz értékek esetében már statisztikailag is szignifikáns a különbség a Cd terhelések között $(\mathrm{p}<0,05)$, azonban a károsító hatás mértéke nem éri el minden esetben a kritikus $10 \%$-os szintet. A 10., 12., és 14. napon mért értékek esetében szintén szignifikáns a különbség az egyes terhelések között, valamint a károsító hatás mértéke is meghaladja a 10\%-ot.

A Cd terhelés hatása az angolperje hajtáshosszára

A következőkben a terhelési periódus utolsó (14.) napján kapott eredményeket részletezem. A kezelések hatására csökkent az angolperje hajtáshossza a kontrollhoz képest (2. táblázat). 
2. táblázat

Kadmium terhelések hatása az angolperje hajtáshosszára (mm)

\begin{tabular}{|c|c|c|c|c|c|c|}
\hline \multirow{2}{*}{$\begin{array}{c}(1) \\
\text { Teszttalaj }\end{array}$} & \multicolumn{5}{|c|}{ (2) Cd-terhelés mértéke $\left(\mathrm{mg} \mathrm{kg}^{-1}\right)$} & \multirow[b]{2}{*}{$\begin{array}{c}\text { (4) } \\
\text { EC értékek }\end{array}$} \\
\hline & 0 & 1 & 2 & 4 & $\begin{array}{c}(3) \\
\text { SzD }_{5}\end{array}$ & \\
\hline Kompolt & 71,5 & 63,2 & 41,6 & 35,3 & 2,8 & $\mathbf{E C}_{\mathbf{1 0}}: 0,57$ \\
\hline Kárositó hatás (\%)(5) & & 11,6 & 41,8 & 50,6 & & $\mathbf{E C}_{\mathbf{2 0}}: 1,34$ \\
\hline Nagyhörcsök & 78,4 & 63,4 & 44,3 & 32,1 & 3,4 & $\mathbf{E C}_{\mathbf{1 0}}: 0,37$ \\
\hline Kárositó hatás (\%)(5) & & 19,1 & 43,5 & 59,1 & & $\mathbf{E C}_{20}: 1,05$ \\
\hline Nyíregyháza & 68,0 & 61,2 & 44,9 & 33,5 & 3,1 & $\mathbf{E C}_{10}: 0,65$ \\
\hline Kárositó hatás (\%)(5) & & 11,5 & 34,0 & 50,7 & & $\mathbf{E C}_{\mathbf{2 0}}: 1,42$ \\
\hline Őrbottyán & 67,7 & 58,5 & 43,2 & 40,1 & 2,6 & $\mathbf{E C}_{\mathbf{1 0}}: 0,49$ \\
\hline Kárositó hatás (\%)(5) & & 13,6 & 36,2 & 40,8 & & $\mathbf{E C}_{20}: 1,45$ \\
\hline
\end{tabular}

Megjegyzés: Károsító hatás: A kontrollhoz viszonyított \%-os csökkenés értéke.

A 14. napon a növekedés-gátlás a legkisebb $1 \mathrm{mg} \mathrm{kg}^{-1}$-os terhelés esetén is meghaladta a 10\%-ot minden talaj esetében, míg a legnagyobb $4 \mathrm{mg} \mathrm{kg}^{-1}$-os terhelés esetén ezek az értékek 40,8\% és 59,1\% között voltak.

A legnagyobb növekedésgátlás a $4 \mathrm{mg} \mathrm{kg}^{-1}$-os $\mathrm{Cd}$ terhelésnél a nagyhörcsöki talajban volt megfigyelhető $(59,1 \%)$, a legkisebb pedig az örbottyáni talajban $(40,8 \%)$.

A talajok kadmium-terhelése és a hajtás növekedése (a terhelési periódus 0 . napjához képest) között a regresszióanalízis alapján lineáris összefüggést találtunk. A determinációs koefficiensek $\left(\mathrm{R}^{2}\right)$ alapján több mint $80 \%$-ban a Cd-terhelés hatásának tulajdonítható a hajtáshossz változásának csökkenő tendenciája a növényben. A legintenzívebb növekedésgátlás a kontrollhoz képest a nagyhörcsöki talaj esetében volt tapasztalható, a b-érték ebben az esetben volt a legkisebb (bérték: -11,5; $\mathrm{R}^{2}$ : 0,91). Ezt követi a kompolti (b-érték: $-9,38 ; \mathrm{R}^{2}: 0,87$ ), majd a nyíregyházi talaj (b-érték: $-8,85 ; \mathrm{R}^{2}: 0,92$ ), míg a legkisebb intenzitás az őrbottyáni talajon mutatkozott (b-érték: -7,02; $\mathrm{R}^{2}$ : 0,82). A talaj növekvő kadmium tartalma tehát a nagyhörcsöki talajon csökkentette legjobban a hajtás hosszát a kontrollhoz képest, a további sorrend az angolperjék hajtásában akkumulált eltérő $\mathrm{Cd}$ mennyiségekkel hozható összefüggésbe.

A Tukey teszt alapján a talajok között minden egyes $\mathrm{Cd}$ terhelés esetében szignifikáns a különbség a hajtás hosszának tekintetében $(\mathrm{p}<0,05)$.

A Cd terhelés hatása az angolperje friss hajtástömegére

A növekvő Cd-terhelés toxikus hatása az angolperje friss tömegének csökkenésében igen érzékenyen megmutatkozott, és a regresszióanalízis alapján ez mind a négy talaj esetében $70 \%$ feletti valószínüséggel a Cd toxikus hatásának következménye (3. táblázat). 
3. táblázat

Kadmium terhelések hatása a hajtás friss tömegére (g/edény).

\begin{tabular}{|c|c|c|c|c|c|c|}
\hline \multirow{2}{*}{$\begin{array}{l}\text { (1) } \\
\text { Teszttalaj }\end{array}$} & \multicolumn{5}{|c|}{ (2) Cd-terhelés mértéke (mg kg-1) } & \multirow[b]{2}{*}{$\begin{array}{l}\text { (4) } \\
\text { EC értékek }\end{array}$} \\
\hline & $\mathbf{0}$ & 1 & 2 & 4 & $\begin{array}{l}(3) \\
\text { SzD5\% }\end{array}$ & \\
\hline \multirow{4}{*}{$\begin{array}{l}\text { Kompolt } \\
\text { Kárositó hatás (\%)(5) } \\
\text { Nagyhörcsök } \\
\text { Károsító hatás (\%)(5) } \\
\text { Nyíregyháza } \\
\text { Kárositó hatás (\%)(5) } \\
\text { Őrbottyán } \\
\text { Kárositó hatás (\%)(5) }\end{array}$} & 6,24 & $\begin{array}{l}5,15 \\
17,5\end{array}$ & $\begin{array}{l}4,23 \\
32,7\end{array}$ & $\begin{array}{l}3,40 \\
45,5\end{array}$ & 0,17 & $\begin{array}{l}\mathbf{E C}_{10}: 0,52 \\
\mathbf{E C}_{\mathbf{2 0}}: 1,40\end{array}$ \\
\hline & 6,43 & $\begin{array}{l}5,63 \\
12,5 \\
\end{array}$ & $\begin{array}{l}4,72 \\
26,6\end{array}$ & $\begin{array}{l}4,16 \\
35,4\end{array}$ & 0,15 & $\begin{array}{l}\mathbf{E C}_{\mathbf{1 0}}: 0,79 \\
\mathbf{E C}_{\mathbf{2 0}}: 1,92\end{array}$ \\
\hline & 5,28 & $\begin{array}{l}4,27 \\
19,1 \\
\end{array}$ & $\begin{array}{l}3,54 \\
33,0\end{array}$ & $\begin{array}{l}3,11 \\
41,1\end{array}$ & 0,14 & $\begin{array}{l}\mathbf{E C}_{\mathbf{1 0}}: 0,40 \\
\mathbf{E C}_{\mathbf{2 0}}: 1,41\end{array}$ \\
\hline & 5,34 & $\begin{array}{l}4,29 \\
19,7\end{array}$ & $\begin{array}{l}3,53 \\
33,9\end{array}$ & $\begin{array}{l}3,16 \\
40,9\end{array}$ & 0,17 & $\begin{array}{l}\mathbf{E C}_{\mathbf{1 0}}: 0,35 \\
\mathbf{E C}_{\mathbf{2 0}}: 1,37\end{array}$ \\
\hline
\end{tabular}

Megjegyzés: Károsító hatás: A kontrollhoz viszonyított \%-os csökkenés értéke.

Az angolperje friss hajtástömege minden talaj esetében szignifikáns mértékben csökkent a kontrollhoz képest $(\mathrm{p}<0,05)$. Látható, hogy $1 \mathrm{x}$-es terhelés (talajhatárérték) esetén, több mint 10\%-os csökkenést regisztráltunk a friss tömegben a kontrollhoz képest, a $2 \mathrm{x}$-es terhelés pedig már meghaladja az $\mathrm{EC}_{20}$ értéket.

A legmagasabb Cd terhelési szinten a legnagyobb friss tömeg csökkenés a kompolti talaj esetében volt tapasztalható $(45,5 \%)$, míg a legkisebb a nagyhörcsöki talaj esetében $(35,4 \%)$.

A csökkenés tendenciáját tekintve, legnagyobb mértékben a kompolti talajon csökken a növény friss tömege (b-érték: -0,70; $\mathrm{R}^{2}: 0,81$ ). Ezt követi a nyíregyházi (b-érték: -0,57; $\mathbf{R}^{2}: 0,82$ ), majd az örbottyáni talaj (b-érték: $-0,52 ; \mathbf{R}^{2}: 0,71$ ), míg legkisebb mértékben a nagyhörcsöki talajon (b-érték: $\left.-0,52 ; \mathrm{R}^{2}: 0,74\right)$ csökken a friss hajtástömeg. Ez a sorrend az angolperjék hajtásában akkumulált eltérő Cd mennyiségek miatt alakulhatott ki.

A Tukey teszt alapján az egyes teszttalajok között szignifikáns különbség volt tapasztalható a friss hajtástömeg csökkenésének tekintetében $(\mathrm{p}<0,05)$. Ez alól az egyetlen kivétel a nyíregyházi és az örbottyáni talaj eredményei, ahol nem találtunk szignifikáns különbséget a friss hajtástömegek között $(\mathrm{p}=0,14)$.

\section{A Cd terhelés hatása további növényi paraméterekre}

A tesztnövény száraztömegében, és nedvességtartalmában regisztrálható változások nem értékelhetők, mivel a $\mathrm{Cd}$ terhelés függvényében kis mérési intervallumot fedtek le, és az eredmények nem minden esetben érték el a szignifikáns szintet. Ökotoxikológiai szempontból sem lehetett a különbségeket jellemezni, mivel az általunk alkalmazott terhelési szintek egy része az $\mathrm{EC}_{10}$ értéket sem érte el. 
A hajtásban akkumulálódott Cd mennyisége

Az angolperje hajtásában akkumulálódott Cd-mennyiség változását a talajterhelés függvényében a 4. táblázat mutatja be.

4. táblázat

A hajtás Cd-koncentrációja (mg kg-1)

\begin{tabular}{|c|c|c|c|c|c|}
\hline \multirow{2}{*}{$\begin{array}{c}(1) \\
\text { Teszttalaj }\end{array}$} & $\mathbf{0}$ & $\mathbf{1}$ & $\mathbf{2}$ & $\mathbf{4}$ & $(3) \mathbf{S z D}_{\mathbf{5} \%}$ \\
\cline { 2 - 6 } Kompolt & 0,32 & 2,10 & 3,18 & 6,78 & 0,34 \\
Nagyhörcsök & 0,23 & 1,55 & 2,54 & 5,76 & 0,41 \\
Nyíregyháza & 0,24 & 2,01 & 3,07 & 6,59 & 0,37 \\
Örbottyán & 0,25 & 1,69 & 2,72 & 6,09 & 0,40 \\
\hline
\end{tabular}

A 14 napos kadmium-terhelési periódus után a tesztnövény hajtásában, mind a 4 talaj esetében detektálható volt a talaj eredeti nehézfém-tartalmából származó kadmium. A talaj Cd tartalmának növelésével talajonként eltérö mértékben, de nőtt a hajtásban akkumulálódott $\mathrm{Cd}$ mennyiség. Az akkumuláció növekvő tendenciája a növényben a determinációs koefficiensek $\left(\mathrm{R}^{2}\right)$ alapján több mint 95\%-ban a $\mathrm{Cd}$ terhelés hatásának tulajdonítható.

Mennyiségét tekintve, a legnagyobb Cd koncentrációt a hajtásban a $4 \mathrm{mg} \mathrm{kg}^{-1}$ os terhelési szinten, a kompolti talaj esetében mértük, míg ezen a terhelési szinten a nagyhörcsöki talajon volt a legkisebb a hajtás Cd koncentrációja.

A vizsgált terhelési tartományban a talajok kadmium-terhelése és a növény hajtása által akkumulált Cd mennyisége között lineáris összefüggés volt.

A legintenzívebb kadmium akkumuláció a kompolti talaj esetében volt tapasztalható, amit a regressziós koefficiensek is alátámasztanak, mivel a b-érték a kompolti talaj esetében volt a legnagyobb (b-érték: 1,$59 ; \mathrm{R}^{2}$ : 0,96). Ezt követi a nyíregyházi (b-érték: 1,$56 ; \mathrm{R}^{2}: 0,95$ ), majd az örbottyáni talaj (b-érték: 1,$45 ; \mathrm{R}^{2}$ : 0,98), míg a legkisebb intenzitás a nagyhörcsöki talajon mutatkozott (b-érték: 1,38; $\left.\mathrm{R}^{2}: 0,97\right)$.

A Tukey teszt alapján megállapítottuk, hogy szignifikáns különbség van az egyes talajok között az angolperje hajtásában akkumulált $\mathrm{Cd}$ mennyiségét tekintve $(\mathrm{p}<0,05)$. Ez alól két eset kivétel, ahol nem volt különbség az angolperje hajtásainak Cd koncentrációjában: a kompolti és a nyíregyházi talaj között, ahol $(p=0,19)$, illetve a nagyhörcsöki és az őrbottyáni talaj között $(p=0,08)$.

A talajtulajdonságok és a vizsgált növényi paraméterek közötti összefüggések

Három talajtulajdonság esetében találtunk szignifikáns korrelációt összehasonlítva a hajtásban mért Cd koncentrációval: $\mathrm{pH}_{(\mathrm{H} 2 \mathrm{O})}(\mathrm{p}=0,027 ; \mathrm{r}=-0,94)$, $\mathrm{pH}_{\mathrm{KCL}}(\mathrm{p}=0,044 ; \mathrm{r}=-0,91)$, humusz \% (p=0,045; r=-0,89). Ez alapján a talaj pH-ja és humusz-tartalma negatív korrelációban áll a hajtásban akkumulált $\mathrm{Cd}$ mennyiségével.

A talajtulajdonságok és a növény hajtáshosszúsága között a következő szignifikáns korrelációkat találtuk: $\mathrm{NH}_{4}-\mathrm{N} \mathrm{mg} \mathrm{kg}^{-1}(\mathrm{p}=0,037 ; \mathrm{r}=0,91), \mathrm{K}_{\mathrm{A}}(\mathrm{p}=0,042$; 
$\mathrm{r}=0,88)$, humusz \% ( $\mathrm{p}=0,042 ; \mathrm{r}=0,78)$. Az angolperje hajtáshosszúsága tehát pozitív korrelációban állt a talaj kötöttségével, humusztartalmával, és a benne található ammóniumion mennyiségével.

A növény friss hajtástömegével az alábbi talajtulajdonságok voltak korrelációban: $\mathrm{pH}_{(\mathrm{H} 2 \mathrm{O})}(\mathrm{p}=0,040 ; \mathrm{r}=0,88), \mathrm{CaCO}_{3} \%(\mathrm{p}=0,043 ; \mathrm{r}=0,91), \mathrm{AL}-\mathrm{P}_{2} \mathrm{O}_{5}$ $(\mathrm{p}=0,048 ; \mathrm{r}=0,84)$. Pozitív korreláció áll fenn a növény friss hajtástömege és a talaj desztillált vízzel kimutatható $\mathrm{pH}$-ja, szénsavas mész-tartalma, valamint AL-oldható foszfortartalma között.

\section{Vizsgálati eredmények értékelése}

A BARNA \& FÜLEKY (2007) által kidolgozott angolperje bioteszt módosított változata alkalmas volt különböző típusú és tulajdonságú, kadmiummal szennyezett talajok ökotoxikológiai vizsgálatára.

A talaj $\mathrm{Cd}$ koncentrációjának növekedése statisztikailag is kimutatható károsító hatással volt az angolperje hajtáshosszára és friss hajtástömegére.

Az angolperje hajtáshosszúsága lehet az egyik érzékeny növekedési paraméter a kadmiummal szennyezett talajok toxicitását értékelö biotesztben, mivel több, mint 80 \%-ban a $\mathrm{Cd}$ terhelés hatásának tulajdonítható a hajtáshossz változásának csökkenő tendenciája a növényben. Hasonló eredményre jutottak BARNA \& FÜLEKY (2007).

A növekvő Cd terhelés toxicitása jól nyomon követhető a tesztnövények friss hajtástömegében bekövetkező csökkenés tendenciájának vizsgálatával is. Ezt több mint 70 \%-ban magyarázza a növekvő Cd koncentráció, így az angolperje friss tömege is alkalmas paraméter lehet a kadmiummal szennyezett talajok ökotoxikológiai értékelésére. Ez megegyezik az irodalmi adatokban talált eredményekkel (GOLDA \& KORZENIOWSKA, 2016; BIDAR et al., 2006; BARNA \& FÜLEKY, 2007).

A hajtásban mért Cd-koncentráció sokkal érzékenyebb mutatója lehet a talaj szennyezettségének, mint a talajhatárértékek konkrét számértékei.

$\mathrm{Az}$ ökotoxikológiai tesztek fontos tulajdonsága a gyorsaság. Emiatt a kadmiummal terhelt talajok tesztelése során kerestük azt a legrövidebb terhelési periódust, amely végére a növényi paraméterek kellően differenciálódnak.

A terhelési periódus 10. napján mért hajtáshosszúságok esetében már szignifikáns volt a különbség az egyes Cd terhelések között, és már $1 \mathrm{mg} \mathrm{kg}^{-1}$-os $\mathrm{Cd}$ terhelés esetében is meghaladta a $10 \%$-os értéket a hajtáshosszúság csökkenése a kontrollhoz képest. Mivel az emelkedő Cd terhelési szintek közötti különbségek a 10. napra jól visszatükröződtek az angolperje hajtáshosszúságában, ezért az általunk alkalmazott növényi biotesztben a talajok Cd tartalmának jellemzésére alkalmas $\mathrm{Cd}$ terhelési periódus legrövidebb időtartama 10 nap lehet.

A növények zöldtömegét csak a kísérlet végén határoztuk meg, így lehetséges, hogy az már a 10. napot megelözően is releváns információkkal szolgál. Ennek megállapítására további vizsgálatokra van szükség.

A 10 napos terhelési periódus a növényi biotesztek esetében rövidnek számít, mivel az OECD szárazföldi növényi tesztjében a legrövidebb ajánlott terhelési 
periódus 14 nap. Azonban a korábbi vizsgálatok ennél jóval hosszabb terhelési periódusokat is szükségesnek tartottak (OECD, 2003; GOLDA \& KORZENIOWSKA, 2016; BARNA \& FÜLEKY, 2007; LEHOCZKY et al., 2002).

A magyar szabványok között megtalálható fehér mustár (Sinapis alba L.) teszt az általunk alkalmazott biotesztnél jóval rövidebb, mindössze 3 napos. Azonban ennek végpontja a csírázás-, valamint a gyökérnövekedésgátlás, és a rövid időtartama miatt a hajtás paramétereinek (hajtáshossz, zöldtömeg) vizsgálatára nem ad lehetőséget (MSZ 21976-17, 1993).

A bakteriális tesztek időtartama szintén rövidebb. A Pseudomonas fluorescens, valamint az Azotobacter agile teszt időtartama egyaránt 48 óra. Azonban az érzékenységük jelentősen eltér a növényi tesztektől. (MSZ 21470-88, 1993; MSZ 21978-30, 1988; BABICH \& STOTZKY, 1985, BARNA \& FÜLEKY 2007).

A talajtulajdonságok nagymértékben befolyásolták az angolperjével végzett bioteszt eredményét, azonban vizsgálatunkban 4 egymástól jelentősen eltérő talajon is sikerrel alkalmazható volt a módszer. Ez alapján az angolperje, mint tesztnövény, alkalmas a talajok kadmium-szennyezettségének környezettoxikológiai értékelésére, és jelzés értékü, kiegészítő információt adhat egy talajszennyezettségi határértéket meghaladó $\mathrm{Cd}$ terheléssel kapcsolatban.

A módszer megfelel az ökotoxikológiai tesztekkel szemben támasztott követelményeknek is, mivel egy tesztszervezet élettani jelenségeit vizsgálja a szennyezőanyag (jelen esetben a kadmium) hatására, továbbá könnyen elvégezhető, müszert nem igényel, így kivitelezési költsége is alacsony (GRUIZ et al., 2001; CARDOSO \& ALVES, 2012).

Véleményünk szerint célszerü lenne elvégezni a kísérletet más nehézfémekkel is, de a módszer alkalmas lehet egyéb talajszennyezö-anyagok (pl.: szerves szennyezőanyagok, hulladékkivonatok) vizsgálatára is.

\section{Összefoglalás}

A kadmium felhalmozódása a talajban humánegészségügyi, ökológiai, és biológiai kockázatokkal jár. Korábbi vizsgálatok alapján kiderült, hogy az angolperje (Lolium perenne L.) hajtáshosszúságára és friss tömegére gyakorolt károsító hatás jó mutatója a teszttalaj kadmium-szennyezésének.

Kísérletünkben 4 különböző termőhelyröl származó talajt használtunk fel, melyek tulajdonságai jelentősen eltértek egymástól. Az angolperjét alkalmazó növényi bioteszt első periódusában 6 nap alatt egyenként $2-2$ g desztillált vízzel átitatott háztartási vattán 2-2 g angolperje magból előneveltük a növényeket. A 7. napon az előnevelt csíranövények a vattával együtt a kadmiummal terhelt talajmintákra kerültek. Négy szinten vizsgáltuk a kadmiumterhelés hatását: $1 \mathrm{~kg}$ talajra számítva 0, 1, 2 és 4 mg kadmium kezelést alkalmaztunk kadmium-acetát formájában. A tápanyaghiányos első periódus után a csíranövények intenzíven vették fel a táp és toxikus anyagokat a talajokból. 14 napos terhelés után mértük a hajtások friss-, ill. száraztömegét, nedvességtartalmát, valamint kadmiumkoncentrációját. Ezen kívül 2 naponta mértük a növények hajtáshosszát. 
Az alkalmazott kezelésekben a kadmium mind a 4 talaj esetében statisztikailag igazolható mértékben csökkentette az angolperje hajtáshosszát és friss tömegét, és a károsító hatás arányban volt az alkalmazott dózissal. Az angolperje hajtáshosszúságában és friss tömegében már $1 \mathrm{mg} \mathrm{kg}^{-1}$-os terhelés esetén is több mint $10 \%$-os csökkenés volt tapasztalható a kontrollhoz képest. A legnagyobb adagú kezelés esetében a hajtáshossz csökkenése meghaladta a $40 \%$-ot, míg a friss tömeg csökkenése a $35 \%$-ot mind a négy talaj esetében.

A növekvő kadmium adagok hatására szignifikánsan nőtt a hajtás $\mathrm{Cd}$ koncentrációja. Az angolperje az alacsony pH-jú, és kisebb humusztartalmú talajból több kadmiumot vett fel, és akkumulált a hajtásban.

Az eredményeink alapján az angolperje bioteszt alkalmas különbözö talajok kadmium szennyezésének jellemzésére.

Kulcsszavak: kadmium, angolperje, talajszennyezés, növényi bioteszt

\section{Irodalom}

6/2009. (IV. 14.) KvVM-EüM-FVM együttes rendelet a földtani közeg és a felszín alatti vízszennyezéssel szembeni védelméhez szükséges határértékekröl és a szennyezések méréséről. Magyar Közlöny 2009/51. (IV. 14.), pp 1439814413.

Alloway B.J. (1995): Heavy metals in soils. Blackie Academic and Professional, London. 368.

BABICH H., STOTZKY G. (1985): Heavy metal toxicity to microbe-mediated ecologic processes: a review and potential application to regulatory policies. Environ. Res. 36: 111-137.

BARCSÁK Z. (2004): Biogyepgazdálkodás. Mezőgazda Kiadó, Budapest. 20-22.

BARNA SZ., FÜLEKY GY. (2007): A talajok Cd-, Pb- és Cu-szennyezettségének értékelése gyors növényi bioteszttel. Agrokémia és Talajtan 56. (2) 285-300.

Bidar G., Garcon G., Pruvot C., Dewaele D., Cazier F., Douay F., Shirali P. (2006): Behavior of Trifolium repens and Lolium perenne growing in a heavy metal contaminated field: Plant metal concentration and phytotoxicity. Environmental Pollution, 147: 546-553.

Cardoso E. J. B. N., Alves P. R. L. (2012): Soil Ecotoxicology. In: Ecotoxicology. (Ed: BEGUM, G), InTech Europe, Rijeka, 27-50.

FILEP GY. (1998): Behaviour and fate of Pollutants in Soil. In: Soil Pollution. (Ed: FILEP, GY.), Agricultural University of Debrecen, Debrecen, 23-51.

GOLDA S., KORZENIOWSKA J. (2016): Comparison of phytoremediation potential of three grass species in soil contaminated with cadmium. Environmental Protection and Natural Resources, 27., No. 1: 8-14.

Göthberg A., Greger M., Holm K., Bengtsson B.E. (2004): Influence of nutrient levels on uptake and effects of mercury, cadmium, and lead in water spinach. Journal of Environmental Quality 33: 1247-1255.

Gruiz K., HorvÁTH B., MolNÁR M. (2001): Környezettoxikológia Vegyi anyagok hatása az ökoszisztémára. Müegyetemi Kiadó, Budapest. 171. 
JONES L. H. P, JARVIS S. C. (1981): The fate of heavy metals. In: The chemistry of soil processes (Ed. GREENLAND, D.J., HAYES, M.H.B.), Wiley, Chichester, 599.

Kabata-Pendias A. (2010): Trace Elements in Soils and Plants, Fourth Edition. CRC Press, Boca Raton. 287-301.

KÁDÁR I. (1995): Környezet és természetvédelmi kutatások: A talaj-növény-állatember tápláléklánc szennyeződése kémiai elemekkel Magyarországon. Budapest: A Környezet- és Területfejlesztési Minisztérium és az MTA Talajtani és Agrokémiai Kutató Intézete kiadványa. 169-290.

KIRKHAM M. B. (2006): Cadmium in plants on polluted soils: Effects of soil factors, hyperaccumulation, and amendments. Geoderma, 137: 19-32.

LEHOCZKY É., NÉMETH T., KISS Zs., SZALAI, T. (2002): Cadmium and Lead Uptake by Ryegrass, Lettuce and White Mustard Plants on Different Soils. Agrokémia és Talajtan, 51, (1-2): 201-210.

LEHOCZKY É., SZABADOS I., MARTH, P. (1996): Cd content of plants as affected by soil Cd concentration. Commun. Soil Sci. Plant Anal. 27: 1765-1777.

Mengel K., KirkBy E. A., Kosegarten H., APPel T. (2001): Elements with More Toxic Effects. Principles of Plant Nutrition, 5th Edition. 657-673

MURÁNYI A., FÜLEKY GY., G. JóZEFACIUK (1997): Ammónium-felvétel hatása a gyökérkörnyezet savanyodására és az angolperje csíranövény kadmiumfelvételére. Agrokémia és Talajtan, 46: 197-206.

MSZ 21470-88 (1993): Környezetvédelmi talajvizsgálatok. Pseudomonas fluorescens talajtoxicitási teszt.

MSZ 21976-17 (1993): Települési szilárd hulladékok vizsgálata. Csíranövényteszt.

MSZ 21978-30 (1988): Veszélyes hulladékok vizsgálata. Azotobacter agile teszt

NOOMAN H. J. \& FÜLEKY GY. (1989): Gyors bioteszt a talaj tápelem-szolgáltató képességének meghatározására. Agrokémia és Talajtan, 38: 121-142.

(OECD) Organisation for Economic Co-operation and Development (2003): OECD Guideline for the testing of chemicals. Proposal for updating guideline 208. Terrestrial Plant Test: 208: Seedling Emergence and Seedling Growth Test

Ramos I., Esteban E., Lucena J. J., Garate A. (2002): Cadmium uptake and subcellular distribution in plants of Lactuca sp. Cd-Mn interaction. Plant Science, 162: 761- 767.

RivetTA A., NEGRINI N., COCUCCI M. (1997): Involvement of Ca2+-calmodulin in $\mathrm{Cd} 2+$ toxicity during the early phases of radish (Raphanus satuvus L.) seed germination. Plant Cell Environ. 20: 600-608.

SAPPIN-Didier V., VAnsuYts G., Mench M., BRiat J. F., (2005): Cadmium availability at different soil $\mathrm{pH}$ to transgenic tobacco overexpresing ferritin. Plant and Soil, 270: 189-197.

Sauvé S., Manna S., Turmel M. C., Roy A.G., Courchesne F., (2003): Solid solution partitioning of $\mathrm{Cd}, \mathrm{Cu}, \mathrm{Ni}, \mathrm{Pb}$, and $\mathrm{Zn}$ in the organic horizons of a forest soil. Environmental Science and Technology, 37: 5191-5196

SIMON L., VÁGVÖlgYI S., GYÖRI Z. (1999): Kadmium-akkumuláció napraforgóban. Agrokémia és Talajtan. 48.(1-2): 99-109. 
SZABÓ L., FODOR L. (1998): Investigation of mobility and availability of some heavy metal in field conditions. In: Soil Pollution, (Ed.: Filep Gy.) Agricultural University of Debrecen, Debrecen 132-137.

Tudoreanu L., Phillips C. J. (2004): Modeling cadmium uptake and accumulation in plants. Advances in Agronomy 84: 121-157.

WuANA R. A., OKIEMEN F. E. (2011): Heavy Metals in Contaminated Soils: A Review of Sources, Chemistry, Risks and Best Available Strategies for Remediation, International Scholarly Research Network, ISRN Ecology, Volume 2011, Article ID 402647, 20 pages

\section{Investigation of soil cadmium pollution using a ryegrass (Lolium perenne $\mathrm{L}$.) biotest}

\section{MóNOK and G. FÜLEKY}

Department of Soil Science and Agricultural Chemistry, Institute of Environmental Science, Faculty of Agricultural and Environmental Sciences, Szent István University, Gödöllő

\section{Summary}

Cadmium accumulation in soils causes ecological, biological and human health risks. Previous studies have shown that reductions in the shoot height and fresh biomass of ryegrass (Lolium perenne L.) are a sensitive indicator of the cadmium pollution level in soils.

Four soils with different types and properties were included in the experiment. In the first period of the biotest, $2 \mathrm{~g}$ cotton-wool pads moistened with distilled water were planted with $2 \mathrm{~g}$ of perennial ryegrass seeds and the seedlings were grown for 6 days. On the 7th day the cotton-wool pads containing the seedlings were placed on soils polluted with four levels of cadmium: $0,1,2$ and $4 \mathrm{mg} \mathrm{Cd} \mathrm{kg}^{-1}$ soil, added to the soil in the form of cadmium acetate. After a first nutrient-deficient period, the seedlings took up nutrients and toxic substances intensively from the soil samples. After a 14-day period of soil-plant contact the fresh biomass, dry biomass and Cd concentration of the shoots were measured, in addition to which the shoot height was measured every 2 days.

Cadmium treatment significantly reduced the shoot height and fresh weight of ryegrass in all the tested soils, and the damaging effect was proportional to the applied dose. A reduction of more than $10 \%$ in the shoot height and fresh weight were observed even at a Cd pollution level of $1 \mathrm{mg} \mathrm{Cd} \mathrm{kg}^{-1}$ soil. At the highest $\mathrm{Cd}$ level the decrease in shoot height was more than $40 \%$ and the decrease in fresh weight more than $35 \%$ in all the soils.

The increasing level of $\mathrm{Cd}$ application significantly increased the $\mathrm{Cd}$ concentration of the shoots. More $\mathrm{Cd}$ was accumulated in ryegrass shoots on soils with low $\mathrm{pH}$ and low organic matter content. 
The results indicate that the ryegrass biotest method is suitable for the characterization of $\mathrm{Cd}$ contamination in different soils.

Keywords: cadmium, ryegrass, soil pollution, biotest

\section{Tables and figures}

Table 1. Soil types and properties. (1) Location. (2) Type of soil. a) brown forest soil; b) chernozem soil; c) sandy soil. (3) Humus \%. (4) Salt \%. (5) $\mathrm{HNO}_{3}$ extract.

Table 2. Effect of Cd treatment on the shoot height (mm). (1) Test soil. (2) Level of $\mathrm{Cd}$ (mg Cd/kg soil). (3) $\mathrm{LSD}_{5 \%}$. (4) EC values. (5) Damaging effect. Note: Reduction compared to the control (\%).

Table 3. Effect of Cd treatment on the fresh weight of the shoots ( $\mathrm{g} / 200 \mathrm{~g}$ soil). (1) Test soil. (2) $\mathrm{Cd}$ treatment (Cd $\mathrm{mg} / \mathrm{kg}$ soil). (3) $\mathrm{LSD}_{5 \%}$. (4) EC values. (5) Damaging effect. Note: see Table 2.

Table 4. Cd concentration of the shoots (mg/kg dry matter). (1) Test soil. (2) Cd treatment (Cd mg $/ \mathrm{kg}$ soil). (3) $\mathrm{LSD}_{5 \%}$.

Figure 1. Increase in shoot height during the pollution period (KO: Kompolt; NH: Nagyhörcsök; NY: Nyíregyháza; ÖB: Örbottyán). Horizontal axis: Pollution period (days). Vertical axis: Shoot height (mm). (1) Brown forest soil. (2) Chernozem soil. (3) Acidic sandy soil. (4) Calcareous sandy soil. 